\title{
Chapter 4 \\ Teacher Design Teams for School-Wide \\ Curriculum Development: Reflections on an Early Study
}

\author{
Adam Handelzalts, Nienke Nieveen, and Jan Van den Akker
}

\section{Introduction}

From a comparative European perspective, the Netherlands can be characterised as a nation with a highly decentralised curriculum policy (Kuiper, Van den Akker, Hooghoff, \& Letschert, 2006; Nieveen \& Kuiper, 2012; Nieveen, Van den Akker, \& Resink, 2010). Ambitions for large-scale and 'top-down' curriculum reform have usually been modest and there is continual balancing between curriculum freedom and regulation (Kuiper, Nieveen, \& Berkvens, 2013; Nieveen, Sluijsmans, \& Van den Akker, 2014). Schools at the primary and junior secondary levels have much autonomy in deciding about their local curriculum. However, it often appears very challenging for schools and teachers to utilise that curriculum space fruitfully. The situation is somewhat different in senior secondary education where, over the last two decades, various efforts have been made for more centralised curriculum change. However, those efforts have resulted in rather overloaded and fragmented programs with limited implementation success.

The extent to which the goals and contents of (compulsory) education should be regulated has been a complicated balancing act. A recent review of curriculum trends in the Netherlands (SLO, 2015) concluded with various recommendations, including some that seem relevant for this context:

\footnotetext{
A. Handelzalts $(\square)$

Teacher Education Department, Free University, Amsterdam, The Netherlands

e-mail: a.handelzalts@vu.nl

N. Nieveen

ELAN Department of Teacher Development, University of Twente,

Enschede, The Netherlands

e-mail: n.m.nieveen@utwente.nl

J. Van den Akker

University of Twente, Enschede, The Netherlands
}

(C) The Author(s) 2019

J. Pieters et al. (eds.), Collaborative Curriculum Design for Sustainable

Innovation and Teacher Learning, https://doi.org/10.1007/978-3-030-20062-6_4 
1. There is a need for concise but clear curriculum frameworks that offer welldefined direction and space for schools and teachers, in combination with considerable investments into the curricular expertise of teachers and school leaders to strengthen their capacity for utilising the space productively for school-based curriculum development.

2. Those curriculum frameworks (for various subjects and sectors of schooling) need justification in a coherent, overarching vision of the main purposes of teaching and learning.

During 2016, a national dialogue was conducted to develop and discuss such an integral curriculum vision. Initial reactions to the resulting advisory report (see www.onsonderwijs2032.nl) made it clear that, not surprisingly, it will not be easy to reach consensus on a 'national' vision of the major aims and contents of learning. However, all reactions underlined the need to give teachers a stronger role in curriculum development, deciding upon their own curriculum preferences and options, in order to realise context-specific solutions that involve ownership and commitment at the school level. As there is also a growing awareness of the complexities and timeframe involved in introducing, realising and sustaining curriculum change, the learning processes of schools and teachers themselves have to come more to the forefront of curriculum improvement.

This current trend for school-based curriculum development makes it interesting to have a retrospective view, with reflection upon a study that was conducted in earlier days on the role of teacher design teams in the context of local curriculum renewal. In the next sections (the main part of this chapter) we will first report on this study, as was also done in a previous ECER paper (Nieveen, Handelzalts, Van den Akker, \& Homminga, 2005). The study centred on the potentials of teacher design teams as a means to integrate curriculum development, teacher development and school organization development. Here, teacher collaboration was seen as essential to bridge the gap between the work of individual teachers (within their own subjects and classrooms) and school-wide aspirations. The chapter provides the rationale behind teacher design teams together with findings from the school site. In the last section we will reflect upon the findings, taking into account more recent trends in policy, practice and research since 2005.

\section{Teacher Design Teams: A Scenario for School-Based Curriculum Renewal}

The study that we report here was conducted in the period 2002-2004. At the time we viewed the long-range, collaborative activities of teachers, focusing on curriculum design and discourse within their own school context, as crucial for the kind of teacher learning that can have a profound impact on student learning (cf. Ball \& Cohen, 1996; McLaughlin \& Talbert, 2001; Shulman \& Sherin, 2004). We referred 
to such teams of teachers who are involved in joint curriculum design efforts as Teacher Design Teams (TDTs). As this study was conducted as (probably) the first one in the field to use the label of TDTs, no sources were yet available that discussed the concept of TDTs. In this section, we present (by and large in our wordings from that time) the ideas, experiences and sources that assisted and inspired us when we were building our understanding of the rationale behind these teacher design teams. First, we will provide our main line of reasoning about why teacher collaboration in curriculum design is important for school-wide curriculum improvement. Then, we will elaborate on the phenomenon of teacher design teams itself and on suitable school conditions under which it may flourish.

\section{School-Based Curriculum Development and Teacher Development}

As changes in the curriculum (including its aims and objectives, subject matter, learner and teacher activities, resources, assessment procedures) have great potential to impact student experiences and performance, schools should focus on improving their school-wide curriculum when striving after school improvement (cf. Hopkins, 2001). This section elaborates on key roles of teachers and teacher collaboration in school-wide curriculum development.

\section{Teachers as Learners and Designers}

Teachers play crucial roles within the context of school-wide curriculum improvement. Consequently, several authors have convincingly recommended putting teachers-as-learners at the forefront of curriculum change (cf. Black \& Atkin, 1996; Putnam \& Borko, 2000). This was succinctly captured by Stenhouse (1975) in a well-known slogan: "No curriculum change without teacher change". This type of teacher learning can be sorted into four categories (Kwakman, 2003): reading and observing (in order to collect new knowledge and information); experimenting (as an intentional effort by teachers to try something new within the classroom); reflecting (as a prerequisite for recognising and changing routine behaviour); and collaborating (to provide teachers with support for learning and feedback and to bring about new ideas and challenges). These categories are not exclusive and should preferably be combined in the process of professional development. Teacher learning is becoming more and more an on-going process and not as limited to a 'one-shot' workshop at an external location (Hargreaves, Earl, Moore, \& Manning, 2001). In order to overcome transfer problems, teacher learning should be embedded in their daily practice. The integration of work and learning processes is therefore seen as a necessary condition for change and improvement at both the individual and organisational level (Kwakman, 2003). 
In the meantime, teachers-as-designers in curriculum change efforts have been gaining attention as well, as the 'enactment' perspective on implementation (teachers and learners together create their own curriculum realities) seems more appropriate (cf. Snyder, Bolin, \& Zumwalt, 1992) than the 'fidelity' perspective (teachers faithfully following curricular prescriptions from external sources). For that reason, teachers' active involvement in rethinking and planning the new curriculum needs to be emphasised. According to Skilbeck (1998), there is a great need to encourage teachers to get involved more fully in such curriculum development processes. In contrast to organizational issues, the focus on improving the curriculum is intrinsically motivating to teachers. It is appealing to them to put effort into planning the actual learning processes of their students in their own subject-matter domain (cf. Black \& Atkin, 1996; Grossman \& Stodolsky, 1995). Additionally, Skilbeck (1998) argued that teacher participation in curriculum development will help improve the quality and relevance what is taught and will strengthen teacher professionalism.

Moreover, teachers' participation in design processes and in implementing these designs in practice is crucial for teacher learning. When designing their future practice, teachers connect their current practice with their needs and wishes. By piloting the design and by reflecting on the experiences and results, teachers become aware of the specific potentials and problems of the new curriculum. Based on such systematic reflections they gain new insights for the (re)design. This can lead to yet another cycle of design, evaluation and reflection. This cyclical process is closely related to that of knowledge-of-practice advocated by Cochran-Smith and Lytle (1999), wherein teachers use their practice to construct knowledge and create change.

In conclusion, a reciprocal relationship between continual teacher development and cyclical curriculum development appears highly desirable. Learning by design, piloting and reflection are at the heart of this relationship.

\section{Importance of Teacher Collaboration in Curriculum Development}

Creating and implementing curriculum change is not an easy task, even for teacher advocates who appreciate and support the change. Many plans to innovate fail at an early stage, and when an attempt does succeed, it is often an isolated effort by one or two teachers. In the long run, most curriculum innovations and projects that rely on such individual teachers' voluntary commitments do not last (Hargreaves, 2003). Part of the problem is that most teachers teach alone in isolated classes without having (or taking) the opportunity to reflect together on their teaching practices, bring in new perspectives, discuss new ideas, give each other feedback on improvement efforts, and jointly come to new initiatives.

In order to get out of their customary isolation, teachers need to collaborate. Little (1990) distinguished four types of such collegial collaboration based on the content of the interaction: story-telling, helping, sharing, and joint work. Although the first three types may assist in maintaining a certain level of workforce stability, they seem less likely to account for high rates of innovation and professional 
development. Therefore, Little (1990) suggested that schools that aim at innovation need teachers who work together on the curriculum renewal and who reflect on and learn from their experiences. Advocates of 'professional learning communities' have offered comparable arguments (e.g., Hord, 2004; Lieberman \& Miller, 2004; McLaughlin \& Talbert, 2001).

A more substantive argument for the importance of joint work can be offered alongside this strategic argument. Collaboration by teachers is indispensable for schools that are working towards a more effective curriculum by bringing greater relevance and coherence into the overall curriculum, such as by making meaningful connections between topics or skills that are usually addressed in different subject areas and/or over longer trajectories.

\section{The Phenomenon of Teacher Design Teams}

Teacher design teams (TDTs) are defined here as groups of teachers of adjacent subjects who cooperate in order to renew and redesign their curriculum and develop themselves professionally (at the individual, group and school level). McLaughlin and Talbert (2001) distinguished two types of professional communities that address curriculum design tasks. The first type enforces traditional methods of teaching. Here teachers work to transmit predetermined course materials and to administer department tests. A second type of professional communities develops innovative methods of instruction that achieve a better fit of the course work to the students. These teams centre their work on students, share responsibility and work on changes concerning all components of a curriculum. The work of the TDTs in our study focused on the second type of professional communities working on curriculum renewal. This section will address the issues of group composition and design activities of such TDTs.

Teachers who collaborate on the renewal of their curriculum may initially feel a loss of individual freedom to act on their personal preferences, without overview by colleagues. Moreover, group settings more readily reveal possible uncertainties in their teaching. Therefore, to collaborate effectively in a TDT teachers need to feel (cf. Hargreaves, 2003; Little, 1990):

- the need for each other's contributions in order to succeed in their own work;

- inspired by new perspectives that their colleagues, especially from other subjects, bring to the design table;

- to some degree a fit between naturally occurring teacher relationships and the artificially constructed links that are introduced (or imposed) in the service of improvement initiatives.

For these reasons, it seems preferable to compose teams of teachers from different but related subject domains.

When it comes to the matter of which teachers need to be actively involved in curriculum development efforts, there are several recommendations in the literature. 
On the one hand, Fullan (1993) asserted that all persons involved should be a change agent. On the other hand, Skilbeck (1998) pointed out that as talents and interests vary, and as there are different kinds of development tasks to perform, matching procedures are inevitable, meaning that not all teachers need to be actively involved in all curriculum development tasks. The two suggestions are not contradictory per se. Variation in level of participation can remain supportive as long as all teachers share a common sense of direction. They all need to be involved, one way or another, in some stages and parts of the process of developing the new curriculum and to feel that they have collective responsibility for it.

The specific group size remains rather arbitrary, as it (to a certain extent) depends on the existing patterns within a school. However, there is some common sense in the message that the team needs to have at least two teachers (preferably more, to stimulate diversity in experiences and perspectives), but no more than about six teachers to maintain a workable organization of collaborative, contentrelated, activities.

\section{Curriculum Development by TDTs}

For both conceptual and practical reasons, curriculum development is often experienced as a complex endeavour. One of the major challenges TDTs confront is creating a curriculum that maintains consistency between all components of a curriculum. In order to address that complexity, we adhere to the metaphor of the so-called 'Curricular Spider Web' (Van den Akker, 2003), which includes ten interconnected issues related to the planning of student learning: rationale, aims and objectives, content, learning activities, teacher role, materials \& resources, grouping, location, time, and assessment. This web helps with systematic design attention to all relevant questions about a curriculum as a plan for learning.

Another challenge refers to the different underlying processes of school and curriculum reform. These can be viewed from a substantive, socio-political and technical-professional perspective (Goodlad, 1994; House \& McQuillan, 1998). When looking at the substantive choices to be made, teachers and other stakeholders implicitly (or sometimes explicitly) search for a balance between three major functions of education (cf. Goodlad, 1994; Van den Akker, 2003), related to the different perspectives of:

- Students: which elements seem of vital importance for learning based on the personal and educational needs and interests of the learners themselves?

- Society: which problems and issues seem relevant for inclusion from the perspective of societal trends and needs?

- Subjects: what is the academic and cultural heritage that seems essential for learning and future development?

In many ways, curriculum development is also a socio-political endeavour in which different values, beliefs and interests constantly play a crucial role. Choosing 
substance and making choices for all other curriculum components usually involves negotiation and compromises between stakeholders at the various curriculum levels (classroom, school and system).

Looking at curriculum development activities from the third (technicalprofessional) perspective, the literature offers many procedural models and strategies for curriculum development. However, in their daily practice, teachers tend to base their design decisions (about matters such as productive learner activities, relevant content, suitable resources, appropriate timing, and so forth) predominantly on their own materials, practical knowledge (what will and will not work in the classroom) including personal survival concerns, and beliefs about professional identity (Black \& Atkin, 1996; Hargreaves et al., 2001; Olson, 2002; Walker, 2003). They use (often externally formulated) goals to validate their initial designs. Gustafson and Branch (2002) pointed out that teachers have less attention available for systematic design (with front-end analysis and rigorous formative evaluation), due to the ongoing nature of classroom instruction, often accompanied by a heavy teaching load and limited resources for development. As long as teachers work individually, these classroom-oriented design approaches may seem to be adequate. However, when teachers are working together as a team on the redesign of their joint curriculum, more effort needs to be put into discussing ideas and consequences and finding ways to come to an agreement. Here, a more systematic approach with some accompanying model may become helpful in order to provide a clear overview of (optional) development stages and activities and to predict timelines and coordinate activities, to reduce the complexity of the decision-making processes, and in communicating about it. Moreover, as teachers tend to put the practical context and the learners at the forefront of curriculum design, a prototyping approach probably suits design teams best. In addition, during an orientation stage, teachers may appreciate the help of a coach when exploring their zone of proximal development. These coaches can draw teachers' attention to interesting ideas and initiatives that are going on at other schools, for instance, by making site visits, attending workshops, and collecting information through literature study and the internet. After this exploration stage, teachers can make their design ideas explicit, and validate and pilot-test the new design. During these prototyping cycles the assistance of an external coach may also be valuable.

\section{Curriculum Development and School Organization Development}

Teacher collaboration in curriculum improvement efforts does not automatically lead to actual and lasting changes. In order to achieve fruitful curriculum renewal in schools, the organizational and working conditions need to support these efforts. The school context should become a powerful, professional learning environment for TDTs. This section will cover three conditions at the school level: an encouraging culture, suitable (infra)structure and powerful support for TDTs. 


\section{Encouraging School Culture}

Culture can be defined as 'the way we do things around here' (Miller, 1998). In order to stimulate the work of TDTs within a context of school-wide curriculum change, the school should foster a culture that addresses collaboration and accountability in a meaningful way and embraces distributed leadership. Hargreaves (2003) has provided a framework for understanding how cultures and performance agreements (contracts) contribute to school renewal, including six culture and contract regimes (see Table 4.1).

Professional learning communities seem to be most supportive for school-wide and long-term change. Schools that foster professional learning communities stimulate working together by teachers, but they also insist that this joint work should consistently focus on improving teaching and learning and use evidence and data as the basis for informing classroom improvement efforts and for solving wholeschool problems. In fostering learning communities, change, and improvement in schools, special attention should be paid to creating shared visions and goals. This is a crucial element in school culture that distinguishes 'improving' schools from 'stuck' schools (Rosenholtz, 1989; Stoll \& Fink, 1996). Without a sense of shared goals in the school, collaborative action is not likely to occur. The existence of shared goals is in itself interrelated with the form of leadership and its distribution in the school (Rosenholtz, 1989).

From the perspective of theory of change, many authors have asserted that leadership shapes the teachers' community. Deep change and secured long-term improvement call for a form of distributed leadership (cf. Hargreaves, 2003; McLaughlin \&Talbert, 2001). Here leaders spread responsibility and ownership of community values throughout the school or department (for instance, by giving substantive roles to department chairs and working groups). Hargreaves (2003) stressed the importance of having a leadership team of complementary strengths: some who can bring about short-term efficiency (managers) and others who can secure long-term improvement (instructional leaders).

Table 4.1 Culture and contract regimes Hargreaves (2003)

\begin{tabular}{l|l|l|l}
\hline \multicolumn{2}{l}{} & Performance contracts \\
\cline { 3 - 4 } & $\begin{array}{l}\text { No collaborative } \\
\text { culture }\end{array}$ & $\begin{array}{l}\text { Po agreements } \\
\text { individualism }\end{array}$ & $\begin{array}{l}\text { Agreements with } \\
\text { accountability }\end{array}$ \\
\hline \multirow{2}{*}{$\begin{array}{l}\text { Collaborative } \\
\text { culture }\end{array}$} & $\begin{array}{l}\text { Collaboration is } \\
\text { encouraged }\end{array}$ & $\begin{array}{l}\text { Collaborative } \\
\text { cultures }\end{array}$ & $\begin{array}{l}\text { Professional learning } \\
\text { communities }\end{array}$ \\
\hline & Collaboration is forced & $\begin{array}{l}\text { Contrived } \\
\text { collegiality }\end{array}$ & Performance training sects \\
\hline
\end{tabular}




\section{Suitable School Structure}

In order to achieve fruitful curriculum renewal, the structures within a school should foster the kind of school culture that was discussed in the former section. Schoolwide innovation processes are helped by at least two structures within a school: school infrastructure and coordination of the curriculum renewal. This section will elaborate on these issues.

Teachers who are involved in TDTs need to work in a context that fosters collaborative design and learning. McLaughlin and Talbert (2001) warned against the assumption that teacher collaboration and invention are self-sustaining or relying on isolated initiatives by individual teachers. According to Hargreaves (1997), there is need for both structural and cultural changes within the infrastructure of schools that provide time and stimulus for those activities that are characteristic of strong professional communities, such as reflection and interaction. This means, for instance, that teacher design teams:

- have time to design and learn that is scheduled together;

- have a suitable workplace for joint work;

- are buffered from outside disruptions;

- are (made) aware of knowledge resources and opportunities for learning inside and outside school and have some budget to work on these opportunities;

- are enabled to negotiate different understandings about practice.

During the process of school-wide curriculum change, the efforts of all TDTs should - at some point - converge into a joint rationale for the school curriculum. A framework for innovation can be helpful in this coordination. However, here a dilemma arises: on the one hand, TDTs need some clear boundaries around the innovation, in order to feel sure that the design they come up with will fit in with the overall rationale of the school. On the other hand, the overall rationale is often far from clear at the start of a change effort. Fullan (2003) even proclaimed that premature clarity is a dangerous thing. Nevertheless, from an early stage on, providing some tentative guidance can be of great help. On top of that, the renewal can be coordinated (cf. Fullan, 1999; McLaughlin \& Talbert, 2001): for instance, crossover structures can support conversation and exchange in order to enable all participants and stakeholders to make connections and can integrate activities around common priorities. Here, principals are essential as integrators and synthesisers. They can help staff to attack incoherence, make connections, and focus on continuity from one program to another. Moreover, they can foster selectivity concerning the aims of the innovation; there is a great need to prevent the school from becoming a 'Christmas tree school' (Bryk et al., 1998a in Fullan, 1999), referring to the situation in which many schools make things worse by taking on every innovation that comes along (so many innovations as decorations, superficial adornment). In all renewal situations, it is advisable to cater for diverse and regular communication to all staff in the school about decisions being made, developments in the process, and progress recorded. This kind of communication helps participants with keeping on track, making their progress visible, and creating a 'common process history'. 


\section{Powerful Support for Teacher Design Teams}

According to Fullan (2001, p. 195): “ “.. all successful schools and districts are proactively plugged into an external network of resources, professional development and other forms of assistance". In that sense, external involvement seems to be essential for success. Still, there is great ambiguity surrounding the kind of external support needed. This section covers three lessons learned from the coaching and consulting literature (Fullan, 2001; Huberman, 1995; Vandenberghe \& Kelchtermans, 2002). First of all, effective coaching means $25 \%$ having good ideas, $75 \%$ helping develop local conditions. Fullan (2001, p. 191) pointed out: "It is not so much the product of reforms that worked elsewhere that needs to be replicated, but the conditions under which the reforms worked." This means that being a consultant requires having good ideas (theories of learning/education) and being very sophisticated about the complexities of relationships and motivations, so that the renewal falls within the 'zone of proximal development' of individual teachers and their schools (theories of change). Further, coaches are resource people, not group leaders. It helps when the team and the coach are clear about the specific expertise that the coach brings in. Huberman (1995) distinguished the following types of expertise: conceptual specialist, educator, didactic specialist, more experienced peer, formative evaluation specialist. On top of that, and especially where teachers are not used to cooperating, TDTs will be helped when a coach facilitates their group process. Finally, coaches have the important task of creating a context for engagement and sense-making. They assist teachers in leaving behind their routine teaching patterns, in reflection, and in making their knowledge explicit and accessible and help the team to come to emotional commitment to taking action. According to Vandenberghe and Kelchtermans (2002), reflection in a team should be broad (covering both technical skills as well as moral and emotional dimensions) and deep (coming to sense-making and preventing false clarity).

\section{Conclusion: Teacher Design Teams as Propelling Force for Integrated School-Wide Curriculum Development}

In order to achieve school-wide curriculum improvement with significant relevance for student learning, teachers need to be put in the forefront. Collaborative teacher learning by cyclical design (including analysis, piloting, reflection and sensemaking) is at the centre of this approach. In order to further the curriculum quality and to encourage teachers' discourse and learning, teachers need to be encouraged to work jointly in small teams, defined here as teacher design teams. On the school level, the work of these TDTs needs to be embraced by a powerful learning and development environment (including supportive school culture, school leadership and support).

The role of TDTs in the intended interplay between curriculum, teachers and school development is visualised in the figure below (Fig. 4.1): 


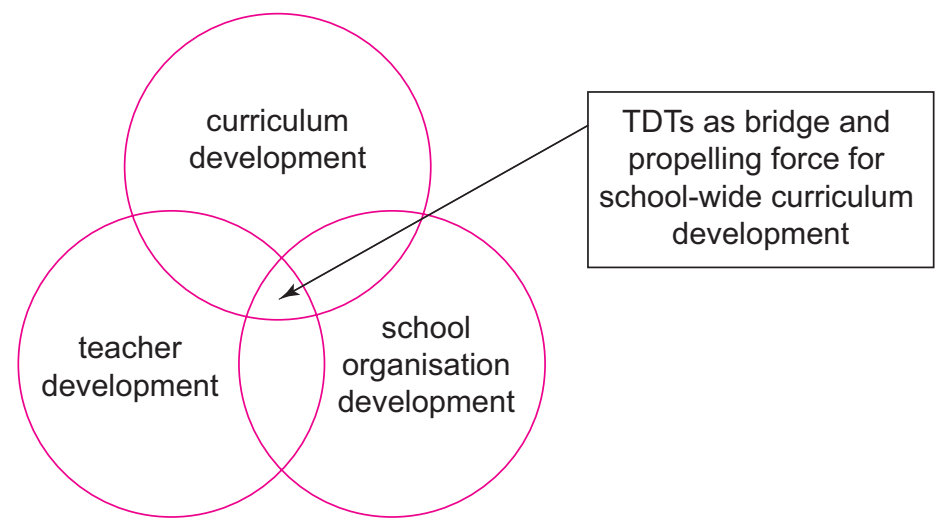

Fig. 4.1 TDTs interacting curriculum, teacher, and school development

\section{Implementation Study}

The rationale behind teacher design teams, as was elaborated in the former section, was the object of research at a junior secondary school that initiated and worked with seven teacher design teams during the period 2002-2004, to foster its school-wide curriculum renewal ambitions. This section will cover an introduction to the pilot site, and the research design, followed by the main findings and conclusions of the study.

\section{Introduction to the Pilot Site}

The pilot site was a school for secondary education with about 500 students. The school-based initiative for curriculum renewal focused on the first two grades of junior secondary (12- to 14-year-olds, about 250 learners). An assessment of baseline practice showed that at the starting point (October 2002), the classroom practices at this school were rather traditional with conventional textbook-driven lesson patterns. To the students, the overall curriculum showed little coherence and the day-to-day practices were fragmented and hardly challenging. However, the school had a pleasant and orderly atmosphere and the relationships between teachers and learners were good. The experienced and dedicated teachers were working in small but rather passive departments. Only limited collaboration was going on between the teachers and professional debate and deliberations were rare. The school professional culture resembled what can be described as 'permissive individualism' (Hargreaves, 2003). Although each individual teacher had some aspirations, there appeared to be a great gap between those articulated aspirations and their daily practices.

In the years preceding 2002, several small-scale innovation initiatives had already been carried out within the school. However, they did not prove to be sus- 
tainable and did not reach all teachers. Meanwhile, the school leaders were working on a - rather open - innovative vision for the first and second grades of junior secondary. The main aspirations in this vision can be summarised as follows:

- from a teacher-oriented program towards a student-centred approach;

- more coherence between subject domains;

- more activity-based learning, with more responsibility and options for learners;

- less fragmented schedule, with longer time periods for learning;

- task differentiation for teachers and support staff;

- more integration of ICT-use.

From 2002 on, the school worked towards these aims. An important characteristic of the innovation process was its school-wide approach and evolving (phased) nature. The approach did not aim at isolated projects in a few subjects, but from the start, active involvement of all junior secondary teachers was stimulated. In order to bridge the gap between the general school level and the individual teachers, the school realised a structure wherein seven teacher design teams were composed (each of about three teachers of related subjects). These teams re-examined their joint domain curriculum and worked together on the design, piloting and implementation of a renewed common curriculum for their domains. In addition, each team was assigned a coach (an external expert in pedagogical content knowledge and curriculum) as facilitator and resource person. Two school leaders (the principal and an innovation manager) were responsible for overall facilitation and coordination. Moreover, as part of the new school structure a core team (with the leaders of each TDT) met regularly, in order to exchange ideas, to discuss problems and needs, and to serve as a platform for coming to some convergence in the innovation.

It took the school one school year (2002-2003) to redesign and develop the entire first grade's curriculum renewal. Starting in August 2003, this curriculum was implemented. During that school year (2003-2004) an implementation study was carried out. The next sub-section will provide a brief overview of the research design of that study.

\section{Research Design}

The main question of the implementation study was: "How does the curriculum renewal process of the school evolve, particularly in the teacher design teams?" The main respondents in this implementation study were the students, teachers, teaching assistants, team coaches, school leader, and innovation manager. The research activities included document analyses (minutes of team meetings, curriculum materials and team curriculum frameworks) and semi-structured (individual or group) interviews with the students, the school leader and innovation manager, the teachers and teaching assistants and the coaches. Interviews with respondents were conducted at the end of the first implementation year (June, 2004). The interviews were 60-90 min long and were all tape-recorded. Interviews were analysed on basis of a flexible analysis scheme that evolved during interview analysis. 


\section{Main Findings}

This section covers the main findings of a study on the first implementation year (2003-2004) at the school site. By June 2004, the TDTs had taught according to the new curriculum during one school year and had worked on the curriculum for the second grade. Table 4.2 provides a description of the work of three TDTs, those for Foreign Languages, Social Studies, and Science (Nature \& Technology) that reflect well the various patterns of all teacher design teams at the school. It is beyond the scope of this chapter to provide detailed information on all of the teams. Table 4.2 serves to summarise the findings of the implementation study, focusing on:

- Characteristics of the TDTs and team development

- Curriculum development within the TDTs

- Teacher development and learning experiences

- School organization development, including school structure, culture and external support.

The following sections give a description of the main findings on these categories, using examples from the three teams whose information is summarised in Table 4.2.

\section{Characteristics of the TDTs and Team Development}

The following seven teacher design teams were composed:

- Foreign Languages: English, German, French

- Social Studies: History, Geography, Home Economics, Religious Studies

- Science (Nature \& Technology): Physics, Technology

- Science (Nature \& Health): Biology, Health Education

- Arts (Music, Drawing, Crafts)

- Mother tongue (Dutch)

- Mathematics.

Most of these teams consisted of more than two teachers. The Social Studies team was the largest, with five teachers. It is interesting to note that the team members on several teams (such as Foreign Languages and Social Studies) did not have much previous cooperation experience. Within these teams, views of the innovation and the commitment levels were quite diverse. The goals of the cooperation varied from subject alignment without integration (for instance, Foreign Languages) to full subject integration (for instance, Nature \& Technology). In particular, the teachers in this latter team had cooperated before and showed great commitment to change. Probably due to their explicit ideas, the team did not feel the need for an external coach, and preferred to work on their own instead. The remaining teams did have an external coach.

Although the teachers had been working in the same school for many years, the teachers on most teams had no prior experience with cooperating with one another. 
Table 4.2 Summary of the findings of the implementation study

\begin{tabular}{|c|c|c|c|}
\hline & $\begin{array}{l}\text { Team \#1- foreign } \\
\text { languages }\end{array}$ & Team \#2 - social studies & $\begin{array}{l}\text { Team \#3 - science } \\
\text { (nature and technology) }\end{array}$ \\
\hline \multirow[t]{5}{*}{$\begin{array}{l}\text { Characteristics of } \\
\text { team }\end{array}$} & $\begin{array}{l}3 \text { experienced } \\
\text { teachers }\end{array}$ & $\begin{array}{l}5 \text { teachers }- \text { varied } \\
\text { experience }\end{array}$ & 2 teachers \\
\hline & Coach & Coach & No coach \\
\hline & No prior cooperation & No prior cooperation & Prior association \\
\hline & $\begin{array}{l}\text { Diverse views of } \\
\text { innovation and } \\
\text { commitment levels }\end{array}$ & $\begin{array}{l}\text { Diverse views of } \\
\text { innovation and } \\
\text { commitment levels }\end{array}$ & $\begin{array}{l}\text { Teacher commitment } \\
\text { and enthusiasm to } \\
\text { project }\end{array}$ \\
\hline & $\begin{array}{l}\text { Goal of cooperation: } \\
\text { alignment but no } \\
\text { integration }\end{array}$ & $\begin{array}{l}\text { Goal of cooperation: not } \\
\text { clear at start }\end{array}$ & $\begin{array}{l}\text { Goal of cooperation: } \\
\text { subject integration }\end{array}$ \\
\hline \multirow[t]{5}{*}{$\begin{array}{l}\text { Team } \\
\text { development }\end{array}$} & $\begin{array}{l}\text { Rough start - finding } \\
\text { common ground } \\
\text { proved difficult }\end{array}$ & $\begin{array}{l}\text { Rough start - finding } \\
\text { common ground proved } \\
\text { difficult }\end{array}$ & $\begin{array}{l}\text { Smooth start and } \\
\text { cooperation }\end{array}$ \\
\hline & $\begin{array}{l}\text { Concrete discussion } \\
\text { of one member's } \\
\text { plans led to open } \\
\text { discussion of all plans }\end{array}$ & $\begin{array}{l}\text { Joint work led to } \\
\text { acquaintance with } \\
\text { colleagues }\end{array}$ & \multirow[t]{4}{*}{$\begin{array}{l}\text { Diverging approaches in } \\
\text { team accepted }\end{array}$} \\
\hline & $\begin{array}{l}\text { Team's cooperation } \\
\text { formalised in concrete } \\
\text { habits }\end{array}$ & $\begin{array}{l}\text { Unbalanced investment of } \\
\text { time and energy in } \\
\text { process led to tension in } \\
\text { cooperation }\end{array}$ & \\
\hline & $\begin{array}{l}\text { Presentation of team's } \\
\text { successes to other } \\
\text { teams strengthened } \\
\text { cohesion }\end{array}$ & $\begin{array}{l}\text { Subject borders still } \\
\text { played a role - little } \\
\text { interaction outside team } \\
\text { meetings }\end{array}$ & \\
\hline & $\begin{array}{l}\text { No further } \\
\text { cooperation outside } \\
\text { direct team activities }\end{array}$ & & \\
\hline \multirow[t]{4}{*}{$\begin{array}{l}\text { Curriculum } \\
\text { development }\end{array}$} & $\begin{array}{l}\text { Material development } \\
\text { occurred separately - } \\
\text { teachers used one } \\
\text { another's ideas }\end{array}$ & $\begin{array}{l}\text { Framework defined } \\
\text { commonly, but } \\
\text { development done } \\
\text { separately; varying levels } \\
\text { of dedication; two } \\
\text { teachers mainly } \\
\text { responsible }\end{array}$ & $\begin{array}{l}\text { Common themes } \\
\text { defined; material } \\
\text { developed individually }\end{array}$ \\
\hline & $\begin{array}{l}\text { New textbooks used } \\
\text { as basis for new } \\
\text { design }\end{array}$ & $\begin{array}{l}\text { Substantial part } \\
\text { independently constructed }\end{array}$ & $\begin{array}{l}\text { One teacher relied on } \\
\text { textbook; another } \\
\text { developed material } \\
\text { independently }\end{array}$ \\
\hline & $\begin{array}{l}\text { In team meeting, } \\
\text { comments on separate } \\
\text { plans led to } \\
\text { adjustments }\end{array}$ & $\begin{array}{l}\text { In team meetings, } \\
\text { discussion of framework; } \\
\text { little discussion of } \\
\text { specific lesson plans }\end{array}$ & $\begin{array}{l}\text { Team meetings ensured } \\
\text { coherence of themes and } \\
\text { exchange of concerns }\end{array}$ \\
\hline & $\begin{array}{l}\text { Use of pilot of } \\
\text { intended work } \\
\text { scheme to evaluate } \\
\text { design }\end{array}$ & $\begin{array}{l}\text { Pilot of an intended } \\
\text { learning activity }\end{array}$ & $\begin{array}{l}\text { Systematic evaluation of } \\
\text { implementation led to } \\
\text { adjustments of learning } \\
\text { materials }\end{array}$ \\
\hline
\end{tabular}


Table 4.2 (continued)

\begin{tabular}{|c|c|c|c|}
\hline & $\begin{array}{l}\text { Team \#1- foreign } \\
\text { languages }\end{array}$ & Team \#2 - social studies & $\begin{array}{l}\text { Team \#3 - science } \\
\text { (nature and technology) }\end{array}$ \\
\hline & & $\begin{array}{l}\text { Formal and systematic } \\
\text { evaluation of } \\
\text { implementation led to } \\
\text { radical adjustments in } \\
\text { structure }\end{array}$ & \\
\hline \multirow[t]{5}{*}{$\begin{array}{l}\text { Professional } \\
\text { development and } \\
\text { learning } \\
\text { experiences }\end{array}$} & $\begin{array}{l}\text { Interaction about } \\
\text { designed materials } \\
\text { and innovation goals } \\
\text { led to new insights }\end{array}$ & $\begin{array}{l}\text { Developing and } \\
\text { constructing material } \\
\text { raised questions and } \\
\text { responses }\end{array}$ & $\begin{array}{l}\text { Developing and } \\
\text { constructing material } \\
\text { raised questions and led } \\
\text { to new insights }\end{array}$ \\
\hline & $\begin{array}{l}\text { Pilot led to new idea } \\
\text { by teacher involved }\end{array}$ & $\begin{array}{l}\text { Implementation and } \\
\text { evaluation led to new } \\
\text { insights, used in planning } \\
\text { for the next grade }\end{array}$ & $\begin{array}{l}\text { Interaction with content } \\
\text { experts on possibilities } \\
\text { was inspiring for } \\
\text { teachers }\end{array}$ \\
\hline & $\begin{array}{l}\text { Implementation } \\
\text { indicated as important } \\
\text { learning process }\end{array}$ & $\begin{array}{l}\text { Leadership role was } \\
\text { significant learning } \\
\text { stimulus for the leader }\end{array}$ & $\begin{array}{l}\text { Implementation and } \\
\text { evaluation led to new } \\
\text { ideas, used in adjusting } \\
\text { design and planning the } \\
\text { for the next grade }\end{array}$ \\
\hline & $\begin{array}{l}\text { In adapting plans, } \\
\text { tension between 'old } \\
\text { habits' and innovation }\end{array}$ & $\begin{array}{l}\text { At the end of } 2 \text { nd year, } \\
\text { team committed to } \\
\text { collaboration; opted to } \\
\text { continue collaboration }\end{array}$ & $\begin{array}{l}\text { At the end of } 2 \text { nd year, } \\
\text { members committed to } \\
\text { collaboration and } \\
\text { innovation; critical of } \\
\text { other teams for lacking } \\
\text { it }\end{array}$ \\
\hline & $\begin{array}{l}\text { At the end of } 2 \mathrm{nd} \\
\text { year, all teachers } \\
\text { committed to } \\
\text { innovation }\end{array}$ & & \\
\hline \multirow[t]{5}{*}{$\begin{array}{l}\text { Perceived role of } \\
\text { school } \\
\text { management }\end{array}$} & $\begin{array}{l}\text { Vague innovation } \\
\text { guidelines and } \\
\text { latitude for team }\end{array}$ & $\begin{array}{l}\text { Vague innovation } \\
\text { guidelines and latitude for } \\
\text { team }\end{array}$ & $\begin{array}{l}\text { Innovation guideline } \\
\text { perceived as vague, } \\
\text { room for team initiatives } \\
\text { and ideas }\end{array}$ \\
\hline & $\begin{array}{l}\text { Lack of } \\
\text { communication with } \\
\text { project management }\end{array}$ & $\begin{array}{l}\text { Decision-making } \\
\text { structure vague }\end{array}$ & $\begin{array}{l}\text { Pacified early incident } \\
\text { concerning external } \\
\text { coach }\end{array}$ \\
\hline & $\begin{array}{l}\text { Responsive when } \\
\text { approached with } \\
\text { requests and } \\
\text { questions }\end{array}$ & $\begin{array}{l}\text { Reserved in informing } \\
\text { activities of team and } \\
\text { intervening }\end{array}$ & \multirow[t]{3}{*}{$\begin{array}{l}\text { Gave member additional } \\
\text { tasks of coordination at } \\
\text { school level }\end{array}$} \\
\hline & \multirow[t]{2}{*}{$\begin{array}{l}\text { Project manager } \\
\text { crucial in securing } \\
\text { consistent } \\
\text { engagement of all } \\
\text { teachers on the team }\end{array}$} & $\begin{array}{l}\text { Responsive when } \\
\text { approached with requests } \\
\text { and questions }\end{array}$ & \\
\hline & & $\begin{array}{l}\text { Reallocated task-hours to } \\
\text { teachers to suit teachers' } \\
\text { investment }\end{array}$ & \\
\hline
\end{tabular}


Table 4.2 (continued)

\begin{tabular}{|c|c|c|c|}
\hline & $\begin{array}{l}\text { Team \#1- foreign } \\
\text { languages }\end{array}$ & Team \#2 - social studies & $\begin{array}{l}\text { Team \#3 - science } \\
\text { (nature and technology) }\end{array}$ \\
\hline \multirow[t]{7}{*}{$\begin{array}{l}\text { Role of external } \\
\text { support }\end{array}$} & $\begin{array}{l}\text { Very proactive in } \\
\text { interventions and } \\
\text { discussions }\end{array}$ & $\begin{array}{l}\text { Reactive, responded to } \\
\text { team's questions }\end{array}$ & $\begin{array}{l}\text { Interaction with content } \\
\text { experts on possibilities } \\
\text { was inspiring for } \\
\text { teachers }\end{array}$ \\
\hline & $\begin{array}{l}\text { Made permanent } \\
\text { connections between } \\
\text { plans and innovation } \\
\text { goals }\end{array}$ & $\begin{array}{l}\text { Assisted in finding } \\
\text { common ground and form } \\
\text { of cooperation }\end{array}$ & \multirow[t]{6}{*}{$\begin{array}{l}\text { Support by researcher in } \\
\text { negotiation with } \\
\text { management concerning } \\
\text { facilities }\end{array}$} \\
\hline & $\begin{array}{l}\text { Controlling of and } \\
\text { commenting on plans }\end{array}$ & $\begin{array}{l}\text { Suggested possible } \\
\text { designs for common } \\
\text { projects }\end{array}$ & \\
\hline & $\begin{array}{l}\text { Structured work } \\
\text { process: meeting's } \\
\text { structure, writing of } \\
\text { common curriculum } \\
\text { plan }\end{array}$ & Support for chairperson & \\
\hline & $\begin{array}{l}\text { Exposed team to } \\
\text { alternative practices }\end{array}$ & $\begin{array}{l}\text { Developed curriculum } \\
\text { materials in accordance } \\
\text { with team plans }\end{array}$ & \\
\hline & $\begin{array}{l}\text { Supplied curriculum } \\
\text { materials }\end{array}$ & $\begin{array}{l}\text { Researcher played role in } \\
\text { designing evaluation }\end{array}$ & \\
\hline & & $\begin{array}{l}\text { Researcher instrumental } \\
\text { in clarifying discussions }\end{array}$ & \\
\hline
\end{tabular}

They spent the first period of team work on getting acquainted with their colleagues and their coach, and on exploring their views on teaching, on the direction for the innovation and on the cooperation process. Most teams encountered difficulties in articulating their wishes and goals and sharing these with their colleagues (the Foreign Languages and Social Studies teams, for instance). This was also complicated, as they perceived the innovation goals and structure to be rather vague. Larger teams involving more different school subjects had greater difficulty negotiating these issues and agreeing on a common work process, as was the case with the Social Studies team. After this initial stage, when teachers had gained more confidence the discussions became more content-related and teachers expressed their wishes and preferences more openly.

Through the concrete work of planning and materials development, teachers got to know each other better. They learned which of their colleagues had the same overall ideas and on which colleagues they could rely on from a process-related point of view. It appeared that, especially in teams with high aspiration levels and/or covering more than two subjects, the collaboration was demanding and more difficult (as was the case with the Social Studies team). Here there was tension regarding the amount of time and energy that all team members needed to invest in the innovation.

Occasions where teams were invited to present their work to their peers worked as catalysts for team development. These events forced the team to formulate a com- 
mon position and to strengthen their identity as a team (as articulated by the Foreign Languages team). Up to this point, the teacher cooperation had remained mainly within the team and subject-borders kept playing a significant role. However, an interesting emerging phenomenon was that teachers who had similar ideas about the innovation but came from various teams seemed to start conferring with one another.

\section{Curriculum Development Within the TDTs}

During the preparation year, the teams operated very differently in designing their curriculum. The characteristics of the process varied from an individualistic approach based on new textbooks and the exchange of inspiring ideas (the Foreign Languages team), to a commonly defined framework and design (the Nature \& Technology and Social Studies teams). For instance, all teachers on the Social Studies team decided together on the themes and organization of a project, while two of its teachers were made primarily responsible for the actual design of the materials. In each team, discussions of the plans led to some adjustments. Those teams that performed a systematic formative evaluation (for instance, Social Studies and Nature \& Technology) came to even more radical adjustments.

The curriculum development activities during the first implementation year were especially geared towards enactment of the designed curriculum for the first grade of junior secondary and the design and development of the curriculum for the second grade. As far as the implementation efforts were concerned, the teams worked mainly on problems related to the actual implementation of their curriculum part. They appeared to have a less keen eye for the consistency of the entire curriculum. It seemed that the design of the curriculum for the second grade went easier, especially because the teams could follow up on earlier decisions already made in the preparation year and because they were more acquainted with the design activities.

\section{Teacher Development and Learning Experiences}

The work of the teams in the preparation year comprised two main activities. First, the teams tried to explore what the school-wide innovation aims might imply for their subjects. They jointly oriented themselves regarding current and alternative practices through consulting the literature, video and internet, making school visits, attending workshops, and contacting publishers. Second, the teams made joint efforts to formulate a tentative curriculum (based on reflection, exchange and deliberation and -in a few instances- on small-scale try-outs of exemplary practices and follow-up design, as happened in the Foreign Languages and Social Studies teams). Based on those activities, teachers developed new subject- and pedagogy-related insights. Moreover, the actual implementation of the first grade curriculum proved to be a key learning opportunity, especially in those teams with high ambitions (for instance, Nature \& Technology). The teachers became aware of the parts that went well and the parts that needed modifications. 
In addition, the school-wide meetings with all teams stimulated the teachers to make their plans explicit, to justify these, to present them to their peers on other teams and to interact with their peers and get suggestions for improvement. This kind of interaction greatly assisted their reflection on the curriculum renewal.

\section{School Organization Development}

Initially, the school leaders faced a dilemma concerning the amount of freedom and restrictions they should give to the teams in the redesign of their curriculum. At the start of the project, they gave great latitude and just a few guidelines to the teams. The leaders formulated a broad innovation framework and held back from interfering with the work of the teams. Coordination and communication structures were somewhat ambiguous. For instance, the core team seemed to function somewhat inefficiently, as not all teams had representatives on it and the discussions were often perceived to be not very productive.

The school structure as realised at the start of the process remained quite stable during the first 2 years of the reform initiative. The teams, core teams and communication channels that were initially established remained the same. In the course of the process the school leaders did, however, change their informal support efforts to be more tailor-made and demand-driven. Although this was done hesitantly, they started to approach the teams more informally and they intervened in the work of teams in order to solve a pending problem or to give direct information on a concrete question, in particular.

The professional culture of the school displayed changes in the course of the process. Increasingly education and teaching became topics of discussion in the teachers' room and school halls as a distinct part of informal discourse. Sharing experiences and information, asking each other for help or assistance, and commenting on one another's work became part of regular practice. This was especially true for the relationships of teachers within the TDTs, but increasingly so also for teachers across teams. School meetings where teams presented their designs and plans and received comments from their colleagues became regular events at the school.

All teams perceived the innovation guidelines as being vague and unclear. This led to different reactions. Whereas one team (Nature \& Technology) used this lack of clear guidance as the basis for deciding on its own course for the innovation, the lack of guidance did lead to confusion and misunderstanding within most teams and to a call for more coordination and a unified school framework. As a consequence, the leadership demanded that the teams deliver their tentative plans. However, this also created difficulty, as some teams were already beyond that initial point in their process and found it redundant, while other teams were not yet able to produce such documentation.

Teams experienced little and unstructured communication from the project management concerning developments in the projects, and decisions made at the school level and at the level of other teams. Some teams (like Foreign Languages) opted as a result to rely on informal and direct contact with the project management to make 
inquiries and requests. Although this appeared to be an effective means of achieving their goals and they were satisfied with the management's response to their requests, they were dissatisfied with the fact that they had to 'chase' the information instead of it being communicated regularly.

Although the management was perceived as being reserved in intervening in the work of the teams and even in enquiring into the details of what they had developed, some practical interventions in team work were appreciated and perceived as effective and necessary. These interventions were directed, for example, at resolving administrative issues to enable the work in the team (Social Studies team) or securing the consistent participation of all team members (Foreign Languages team).

\section{External Support}

With the exception of the Nature \& Technology team, got an external coach. Because of the open innovation framework, the vaguely defined role of coaches, and the fact that the teachers did not know what to expect from the coaches, there was a mismatch of expectations in some instances. A great variety of approaches to coaching and working with the teams was apparent within the school. The coaches varied considerably, especially with respect to their degree of directiveness. Where one coach was very proactive, initiated many interventions, and structured the team's work process (as was the case with the Foreign Languages team) other coaches were more inclined to be more reactive to what was developed within the team, initiating actions only on specific requests by the team (as was the case with the Social Sciences team). This variation was also evident in the types of activities they pursued with the team (such as assisting in construction of materials, structuring team processes, and presenting teachers with alternative practices).

In the preparation year, the role of most coaches was concentrated on helping the team to define their specific innovation framework and plans. Most coaches focused on trying to align the team's plans with those of the school, as was apparent in the Foreign Languages team. This was done by commenting on emerging plans and linking them to the broader framework. In some cases, the coaches helped in writing the plans and supplied useful educational materials. Involvement of the coaches in curriculum evaluation activities appeared to enhance the systematic character of the evaluation. In the 2nd year, when the outlines of the teams' curricula were clearer, this influence of the coach diminished somewhat, although the more proactive coaches, such as the one for the Foreign Languages team, remained dominant in the 2nd year.

\section{Conclusions of the Implementation Study}

The empirical findings showed great variety in the evolving innovation processes of the different teacher design teams. Within one (relatively small) school, seven teams operated in different ways, got diverse forms of external support, perceived the 
school context differently and produced varying products. Based on these findings, we came up with a number of conclusions and accompanying advice for schools, teachers and external coaches that aim at pursuing a teacher design team scenario in the context of school-wide curriculum development.

\section{Characteristics of TDTs}

As far as the group composition is concerned, the great variety across the teams did not lead to transparent suggestions for the future. The larger teams showed more variation in personality and visions. Teams need to have some diversity for inspiration and to have something to discuss. However, if the intentions and motivation to work on the renewal project are too divergent, this may also lead to friction. The smaller teams with less variation among their members were able to arrive fairly early at a common platform of ideas. However, here the innovation process was sometimes hampered by a lack of inspiring ideas and discussions. Based on this, we offer the following suggestion:

- In order to have sufficient effective discourse, external coaches should be especially aware of friction in a team, make this friction explicit to the team and look together for ways to act on it. In smaller teams, more attention should be given to the introduction of possible alternatives and new ideas.

The findings illustrate that in some instances the TDTs decided to divide up their common design tasks among the team members. Although a great deal of cooperation was going on, it did not always lead to joint work and meaningful discussion about these individually completed design tasks. One may wonder how much collaborative learning was going on. This leads to the following suggestion:

- Although a task division approach is understandable from a pragmatic perspective, teams need to pay special attention to stimulating meaningful interaction concerning their design and they need to support their learning process, for instance, by deliberating on a common overall framework, by joint appraisal and piloting of the design and by organizing reflection meetings.

\section{Teacher Development}

The findings show that teachers who were involved in their team's design activities felt that their learning needs became more apparent and clearer as soon as they started experimenting with their designs in daily practice and implementing them. This finding leads to several points for attention:

- Actual implementation leads teachers to reflect on the strengths and weaknesses of their design and to initiate follow-up actions. Given the fact that reflection is such a central element in learning, this reflection process should get specific attention, for instance, from external coaches who provide focus questions before and after the implementation. 
- In order to increase teachers' chance of having multiple reflection experiences, it seems helpful to have ample opportunities for piloting 'experimental' learning and teaching approaches at an early stage of development, instead of waiting till the next year for the implementation of the new or revised curriculum.

In sum, taking the role of teachers as learners and designers seriously calls for an iterative and evolutionary curriculum design approach, with special attention for the reflection process based on experiences with the design in classroom practice.

\section{Curriculum Development}

The curriculum development activities carried out by the teams were rather unstructured and showed some imbalance. Most teams started working on the organizational components of the renewal (timetable, sequence of the content) and put less effort into the implications for their own teaching roles and pedagogical changes. This leads to the following suggestion:

- From a curricular perspective, it is fruitful to make use of the 'Curricular Spider Web', which offers a cadre of ten curriculum components, in order to underline the importance of consistency between all curriculum design choices at the team and school levels.

\section{School Organization Development}

Interesting enough, during the process culture change was not high on the school leaders' priority list. However, based on the findings it becomes clear that the school's professional culture changed from a culture typified as 'permissive individualism' towards a more collaborative culture. On a regular basis, at school meetings and, maybe even more importantly, at informal meetings during breaks, teachers presented and discussed their joint work, shared experiences and information, asked colleagues for assistance, and commented on one another's work. This finding leads to the following suggestion:

- Although more profound results may be accomplished when culture change is stressed more during the process, it seems that the work of TDTs together with regular school-wide meetings has valuable potential in this direction.

The variety in the teams' innovation processes is related to a great dilemma in the process. On the one hand, it is necessary to let teams work on a design that is relevant to them and at a speed that suits them. On the other hand, there is the need to arrive at a coordinated school framework that is coherent, practical and realistic. This dilemma leads to several points for consideration:

- Variation among participants (teachers, teams) should not be regarded as an obstacle, but as a normal feature of development processes. Differences in tasks, 
style, commitment, and support should be expected, and sometimes perhaps even encouraged.

- In order to foster curricular cohesion, much emphasis should be put on (both formal and informal) communication between all stakeholders in the process. All sorts of (ongoing) communication are helpful for stimulating the development process: personal/organizational; formal/informal; written/oral. Documentation of processes and (preliminary) outcomes is beneficial for progress, although overload of bureaucratic paperwork should be avoided.

- The school organization can facilitate the collaborative development activities by creating smart cross-over patterns, by offering adequate working arrangements, and by alert handling of emerging organizational and logistic problems. Leadership tasks and responsibilities should be distributed within the organization.

The external support in these decentralised school improvement processes also brought forward a dilemma. Although there was no single best direction in the innovation process, there was (from a coherence point of view) no complete freedom for the teams. For the coaches, there was tension between being too dominant and steering (pushing the team in a certain direction) and being reactive and somewhat passive (just following the teams and waiting for their initiatives and achievements). The coaches handled this dilemma in various ways, which led to the following suggestions:

- Active deliberation and articulation of the needs and wishes of the team and its coach appear to lead to better alignment of the expectations and a more fruitful innovation process.

- Most teams do expect a proactive coaching style, especially in the early stages. Being only reactive does not seem to be very productive.

- In order to leave behind routine patterns and bring in inspiring ideas that lead to discourse, it seems to be good advice to assist teachers during the orientation stage with exposure to alternative approaches and views.

Finally, no matter how well conceived the innovation approach is, change processes are bound to be turbulent and to create insecurities, tensions and emotions. Thus, the suggestion for all participants is to be tolerant of frustrations, to be keen in identifying and celebrating successes, and to maintain a flexible approach, characterised by experiential learning.

\section{Reflections After More Than a Decade of TDT-Related Studies}

\section{Trends in TDT Approaches}

To our knowledge, this study (that began 15 years ago) was the first study that used the concept of Teacher Design Teams (TDTs), representing the beginning of a research line. 
Since then, this label and its corresponding rationale and approach have become very popular in the Netherlands. Several doctoral dissertations on the TDT approach have been conducted (cf. Bakah, 2011 Handelzalts, 2009; Huizinga, 2014), and a number of other studies regarding TDTs have been published (see overviews in, for example, Huizinga, Handelzalts, Nieveen, \& Voogt, 2014, and this volume).

Perhaps even more remarkable and relevant is the very rapid expansion of TDTs in the practice of curriculum improvement in interaction with teacher professional learning and school development. The TDT approach appears to be very appealing to many practitioners. Moreover, at the policy level, TDTs are also viewed and promoted as a very promising strategy for local educational improvement, as can be observed in documents prepared by the Dutch Ministry of Education.

In many more recent projects, however, TDTs have been applied in settings where teachers from various schools work as a collective. Usually, the emphasis in such multi-school projects is more on fostering the professional learning of teachers (mostly within the same subject) than on school-wide curriculum improvement within a specific school. Many experiences have been gathered on how teacher design teams work, how teachers learn, and how school organization and coaches affect these teams. Although the multi-site, single-subject approach is definitely interesting, it has less to do with the kind of organizational, socio-political dynamics and capacities that are involved in school-specific and school-wide curriculum development endeavours. The challenge of maintaining curricular coherence between subjects is also less at stake. Thus, although the specific combined aspirations for teacher development, curriculum development, and school development in our study and view of TDTs seem not so often pursued, their relevance is perhaps greater than ever, considering the current policy aims introduced at the start of this chapter.

\section{Way Forward: Teacher Design Teams in the Context of Recent Curriculum Policy}

The lessons learned for this original study appear to have particular relevance in view of recent policy developments and school realities, pointing to a renewed strong interest in school-based curriculum development. The importance of team learning and development has been re-discovered and again emphasised, especially for school-specific curriculum renewal (Onderwijsraad, 2017). The findings of our study are, in our opinion, still meaningful and worthwhile, when considering how to address this challenge. For that reason, we conclude this chapter with a summary list of eight major principles and accompanying activities for the work of TDTs in schools that are active in the field of school-based curriculum development (Table 4.3). This list was incorporated in one of the articles about the study that we discussed in this chapter (Nieveen, Handelzalts, \& Van den Akker, 2005). In view of recent trends, the near future will bring ample opportunities to apply and evaluate the scenario of TDTs in the context of school-wide curriculum development, hopefully resulting in refinement and enrichment of the underlying principles. 
Table 4.3 Eight principles for Teacher Design Teams in school-wide curriculum development

Curriculum development - Principles and supportive activities

1. Think big, but start small $\quad$ Picture the school-wide changes

Formulate school-wide $\quad$ Mobilise all teachers

intentions, but work stepwise Elaborate smaller parts that fit the bigger picture

towards these ends

Stimulate relatively rapid alternation of design and try-out

activities to speed up experiential team learning about the

curriculum renewal

Use phases (e.g., per grade instead of all grades at one go)

2. One size does not fit all

Be clear about what the changes entail

Use a common framework, Explain the bandwidth of the framework (degrees of freedom)

but provide room for specific choices

Make room for alternative solutions

Expect teachers to negotiate

Go back and forth between the innovation framework and the room for specific choices

\begin{tabular}{l|l}
\hline $\begin{array}{l}\text { 3. Think broadly, but keep an } \\
\text { eye on the learners }\end{array}$ & Start from a learner's perspective and a vision on learning \\
\hline $\begin{array}{l}\text { Make sure that learners } \\
\text { remain at the centre of the } \\
\text { renewal }\end{array}$ & $\begin{array}{l}\text { Consider consistency by using the curricular spider web for } \\
\text { analysing the current curriculum-in-action, for characterising the } \\
\text { intended curriculum, and for evaluating the renewed curriculum } \\
\text { practice }\end{array}$ \\
\cline { 2 - 2 } & Consider longitudinal consistency among grades as well \\
\hline
\end{tabular}

Teacher development - Principles and supportive activities

\begin{tabular}{l|l}
\hline 4. Work together & $\begin{array}{l}\text { Make TDTs of two or more teachers of (adjacent) subjects who } \\
\text { are responsible for their common curriculum }\end{array}$ \\
\hline $\begin{array}{l}\text { Make collaboration happen } \\
\text { in and amongst teacher } \\
\text { design teams }\end{array}$ & Use a differentiated development approach per TDT \\
\hline $\begin{array}{l}\text { 5. Design in a cyclical } \\
\text { manner }\end{array}$ & Analyse and describe the starting situation at the school \\
\hline $\begin{array}{l}\text { Make use of a cyclical } \\
\text { development approach }\end{array}$ & $\begin{array}{l}\text { Explore the zone of proximal development through collaborating } \\
\text { on orientation about current and alternative practices (site visits, } \\
\text { conversations, literature, experts) }\end{array}$ \\
\hline & Formulate a common platform of ideas for renewal \\
\cline { 2 - 2 } & Design parts of the renewal \\
\hline & Pilot test collaboratively to support common experiences \\
\hline & Reflect on results \\
\hline & Revise the design \\
\hline & Make plans and findings explicit (on paper or other media) \\
\hline
\end{tabular}

School organization development - Principles and supportive activities
6. Create a supportive
Give TDTs responsibility for several years

school culture 
Table 4.3 (continued)

\begin{tabular}{l|l}
\hline Create a culture of & Formulate a (modest) requirement concerning what all TDTs
\end{tabular} responsibility and distributed need to deliver at a minimum

leadership infrastructure

Create an infrastructure that supports the necessary culture
7. Create a supportive

Encourage TDTs to negotiate with the leadership about roles and expectations

Assist TDTs in using the room for freedom (don't fill it up for them too quickly)

Invite teams to look for evidence of the effects and discuss this evidence

Vary in leadership styles: Stay closer to teams who do not have a clear informal leader

Combine a rational and relational approach: visit the TDTs frequently

Be prepared for emotions, tensions and misunderstandings and act on them

Be tolerant of mistakes and insecurity

Notice initial successes and build on them

Take care of facilitation: time for design and collaboration, inspiring work place, budget

Communicate carefully: communicate a lot in various ways

Be responsive to questions and give follow-up

Ask for and use feedback from learners and parents

Formulate and appreciate successes

Coordinate the renewal and take care of syntheses by realising cross-over structures and supporting connections

8. Provide external support

Offer proactive and

Show initiative, but avoid becoming the leader

responsive support
Negotiate about the supportive role

Take care to support the process (listening and observing; differentiating the support, making it possible to express concerns)

Bring in relevant suggestions

Support evaluation activities

Create a context for meaning-making (success experiences, broad and deep reflections, make knowledge gains explicit)

Assist in the determination to become active 


\section{References}

Bakah, M. (2011). Teacher professional development through collaborative curriculum design in Ghana's polytechnics. Doctoral dissertation. Enschede, The Netherlands: University of Twente.

Ball, D. L., \& Cohen, D. K. (1996). Reform by the book: What is-or might be-the role of curriculum materials in teacher learning and instructional reform? Educational Researcher, 25(9), 6-14.

Black, P., \& Atkin, J. M. (Eds.). (1996). Changing the subject. Innovations in science, mathematics, and technology education. London: Routledge.

Cochran-Smith, M., \& Lytle, S. L. (1999). Relationship of knowledge and practice: Teachers learning in communities. Review of Research in Education, 24, 249-305.

Fullan, M. G. (1993). Change forces: Probing the depth of educational reform. London: Falmer Press.

Fullan, M. G. (1999). Change forces: The sequel. London: Falmer Press.

Fullan, M. G. (2001). The new meaning of educational change. New York: Teacher College Press. Fullan, M. G. (2003). Change forces with vengeance. London: Routledge Falmer.

Goodlad, J. I. (1994). Curriculum as a field of study. In T. Husén \& T. N. Postlethwaite (Eds.), The international encyclopedia of education (pp. 1262-1267). Oxford, UK: Pergamon.

Grossman, P., \& Stodolsky, S. (1995). Content as context: The role of school subjects in secondary school teaching. Educational Researcher, 24(8), 5-11.

Gustafson, K. L., \& Branch, R. M. (2002). Survey of instructional development models. Syracuse, NY: ERIC.

Handelzalts, A. (2009). Collaborative curriculum design in teacher design teams. Doctoral dissertation. Enschede, The Netherlands: University of Twente.

Hargreaves, A. (1997). From reform to renewal: A new deal for a new age. In A. Hargreaves \& R. Evans (Eds.), Beyond educational reform: Bringing teachers back in (pp. 105-125). Buckingham, UK: Open University Press.

Hargreaves, A. (2003). Teaching in the knowledge society. Education in the age of insecurity. New York: Teachers College Press.

Hargreaves, A., Earl, L., Moore, S., \& Manning, S. (2001). Learning to change. Teaching beyond subjects and standards. San Francisco: Jossey-Bass.

Hopkins, D. (2001). School improvement for real. London: Routledge Falmer.

Hord, S. (2004). Learning together, leading together. Changing schools through professional learning communities. New York: Teachers College Press.

House, E. R., \& McQuillan, P. J. (1998). Three perspectives on school reform. In A. Hargreaves, A. Lieberman, M. Fullan, \& D. W. Hopkins (Eds.), International handbook of educational change (pp. 198-213). Dordrecht, The Netherlands: Kluwer Academic Publishers.

Huberman, M. (1995). Professional careers and professional development: Some intersections. In T. R. Guskey \& M. Huberman (Eds.), Professional development in education: New paradigms and practices (pp. 193-224). New York: Teachers College Press.

Huizinga, T. (2014). Developing curriculum design expertise through teacher design teams. Doctoral dissertation. Enschede, The Netherlands: University of Twente.

Huizinga, T., Handelzalts, A., Nieveen, N., \& Voogt, J. (2014). Teacher involvement in curriculum design: Need for support to enhance teachers' design expertise. Journal of Curriculum Studies, $46(1), 1-25$.

Kuiper, W., Nieveen, N., \& Berkvens, J. (2013). Curriculum regulation and freedom in the Netherlands: A puzzling paradox. In W. Kuiper \& J. Berkvens (Eds.), Balancing curriculum regulation and freedom across Europe (CIDREE yearbook 2013) (pp. 139-162). Enschede, The Netherlands: SLO. 
Kuiper, W., Van den Akker, J., Hooghoff, H., \& Letschert, J. (2006). Curriculum policy and school practice in a European comparative perspective. In J. Letschert (Ed.), Curriculum development re-invented (pp. 56-77). Enschede, The Netherlands: SLO.

Kwakman, K. (2003). Factors affecting teachers' participation in professional learning activities. Teaching and Teacher Education, 19(2), 149-170.

Lieberman, A., \& Miller, J. (2004). Teacher leadership. San Francisco: Jossey-Bass.

Little, J. W. (1990). The persistence of privacy: Autonomy and initiative in teachers' professional relations. Teachers College Record, 91, 509-536.

McLaughlin, M. W., \& Talbert, J. E. (2001). Professional communities and the work of high school teaching. Chicago: The University of Chicago Press.

Miller, L. (1998). Redefining teachers, reculturing schools: Connections, commitments and challenges. In A. Hargreaves, A. Lieberman, M. Fullan, \& D. W. Hopkins (Eds.), International handbook of educational change (pp. 529-543). Dordrecht, The Netherlands: Kluwer Academic Publishers.

Nieveen, N., Handelzalts, A., \& Van den Akker, J. (2005). Leren van schoolvoorbeelden: Principes voor kansrijke onderwijsvernieuwing [Learning from school examples: Principles for promising educational improvement]. Enschede, The Netherlands: SLO.

Nieveen, N., Handelzalts, A., Van den Akker, J., \& Homminga. S. (2005). Teacher design teams: A scenario for school-based curriculum innovation. Paper presented at ECER, Dublin.

Nieveen, N., \& Kuiper, W. (2012). Balancing curriculum freedom and regulation in the Netherlands. European Educational Research Journal, 11(3), 357-369.

Nieveen, N., Sluijsmans, L., \& Van den Akker, J. (2014). Encouraging curriculum change in the Netherlands: The next episode. In F. Nyhamn \& T. N. Hopfenbeck (Eds.), From political decisions to change in the classroom (pp. 162-183). Oslo, Norway: The Norwegian Directorate for Education and Training.

Nieveen, N., Van den Akker, J., \& Resink, F. (2010). Framing and supporting school-based curriculum development in the Netherlands. In E. H.-F. Law \& N. Nieveen (Eds.), Schools as curriculum agencies: Asian and European perspectives on school-based curriculum development (pp. 273-283). Rotterdam, The Netherlands: Sense Publishers.

Olson, J. (2002). Systemic change/teacher tradition: Legends of reform continue. Journal of Curriculum Change, 34(2), 129-137.

Onderwijsraad. (2017). Een ander perspectief op professionele ruimte in het onderwijs: Versterk vermogen om te handelen vanuit het team [Another perspective on professional space in education: Strengthen agency from the team]. Den Haag, The Netherlands: Onderwijsraad.

Putnam, R. T., \& Borko, H. (2000). What do new views of knowledge and thinking have to say about research on teacher learning? Educational Researcher, 29(1), 4-16.

Rosenholtz, S. J. (1989). Teachers' workplace. The social organization of schools. White Plains, NY: Longman.

Shulman, L., \& Sherin, M. (2004). Disciplinary perspectives on fostering a community of teachers as learners [special issue]. Journal of Curriculum Studies, 36(2), 133-271.

Skilbeck, M. (1998). School based curriculum development. In A. Hargreaves, A. Lieberman, M. Fullan, \& D. W. Hopkins (Eds.), International handbook of educational change (pp. 121144). Dordrecht, The Netherlands: Kluwer Academic Publishers.

SLO. (2015). Curriculumspiegel 2015. Deel A: Generieke trendanalyse [Curriculum mirror 2015. Part A: Generic trend analysis]. Enschede, The Netherlands: SLO.

Snyder, J., Bolin, F., \& Zumwalt, K. (1992). Curriculum implementation. In P. W. Jackson (Ed.), Handbook of research on curriculum (pp. 402-435). New York: Macmillan.

Stenhouse, L. (1975). An introduction to curriculum research and development. London: Heinemann Educational Books.

Stoll, L., \& Fink, D. (1996). Changing our schools. Buckingham, UK: Open University Press. 
Van den Akker, J. (2003). Curriculum perspectives: An introduction. In J. Van den Akker, W. Kuiper, \& U. Hameyer (Eds.), Curriculum landscapes and trends (pp. 1-10). Dordrecht, The Netherlands: Kluwer Academic Publishers.

Vandenberghe, R., \& Kelchtermans, G. (2002). Leraren die leren om professioneel te blijven leren: Kanttekeningen over context [Teachers learning to continue learning professionally: Reflections on context]. Pedagogische Studiën, 79(4), 339-351.

Walker, D. F. (2003). Fundamentals of curriculum. Fort Worth, TX: Harcourt Brace College Publisher.

Open Access This chapter is licensed under the terms of the Creative Commons Attribution 4.0 International License (http://creativecommons.org/licenses/by/4.0/), which permits use, sharing, adaptation, distribution and reproduction in any medium or format, as long as you give appropriate credit to the original author(s) and the source, provide a link to the Creative Commons licence and indicate if changes were made.

The images or other third party material in this chapter are included in the chapter's Creative Commons licence, unless indicated otherwise in a credit line to the material. If material is not included in the chapter's Creative Commons licence and your intended use is not permitted by statutory regulation or exceeds the permitted use, you will need to obtain permission directly from the copyright holder.

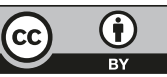

